\title{
Tranebær til forebygging av residiverende urinveisinfeksjoner
}

\author{
Urinveisinfeksjoner behandles med antibiotika. Utstrakt og hyppig bruk \\ kan føre til resistensproblemer og residiver med mer patogene bakte- \\ rier. Kan tranebær brukt forebyggende gi færre infeksjoner og dermed \\ føre til redusert bruk av antibiotika og mindre problemer med antibio- \\ tikaresistens?
}

Se også kunnskapsprøve på www.tidsskriftet.no/quiz

Amerikansk tranebær eller stortranebær (Vaccinium macrocarpon Ait.) tilhører lyngfamilien (Ericaceae). I flere tiår er de blitt brukt $\mathrm{i}$ behandling og forebygging av urinveisinfeksjoner. Tranebær (V macrocarpon) finnes på markedet $\mathrm{i}$ form av juice, tabletter og kapsler. Tranebærprodukter er sannsynligvis i utstrakt bruk i Norge. Det er imidlertid vanskelig å få oversikt over det nøyaktige forbruk, da produktene selges via apoteker, helsekostforretninger, dagligvarebutikker, over Internett og på postordre. I en studie fra 2004 fant man at tranebær ble brukt av $3 \%$ av norske gravide (1).

\section{Materiale og metode}

Grunnlaget for artikkelen er systematiske litteraturs $ø$ i PubMed og Embase (e-ramme 1) $(2-4)$.

\section{Innholdsstoffer}

Tranebær innholder store mengde organiske syrer (sitronsyre, askorbinsyre, kinasyre, eplesyre, oksalsyre, salisylsyre og benzosyre). De smaker svært surt, og saften/juicen er derfor ofte tilsatt store mengder sukker. Bærene inneholder $i$ tillegg en mengde andre stoffer, deriblant fruktose, katekiner og flavonoider (bl.a. proantocyanidiner) (5). Proantocyanidinene regnes som «virkestoffet» $i$ tranebær. De består av tre epikatekinenheter koblet sammen via en A-type interflavanoid binding (6). Denne typen trimere er ikke tidligere isolert fra andre bær.

Det er viktig at tranebærprodukter er standardisert - fordi mengden av de ulike innholdstoffene kan variere avhengig av vekstvilkår, dyrkningsmetoder, innhøstningstidspunkt, tilberedning etc.

\section{Virkningsmekanisme \\ I 2000 identifiserte Foo og medarbeidere tre proantocyanidiner (trimere) fra tranebær som hemmet adheranse av E coli-arter med P-fimbrier til uroepitelceller in vitro (6) (fig 1, fig 2). To uavhengige dobbeltblindede, randomiserte, placebokontrollerte kryssun-}

dersøkelser $(\mathrm{n}=20$ og $\mathrm{n}=8)$ viste begge en signifikant, doseavhengig reduksjon av E colis evne til å adherere til uroepitelceller in vitro assosiert med inntak av tranebærjuice (morgenurin etter inntak av $250 \mathrm{ml}$ eller 750 $\mathrm{ml}$ tranebærjuice eller $108 \mathrm{mg}$ og $36 \mathrm{mg}$ tranebær ved middagstid). Inntaket av tranebær i studien tilsvarte henholdsvis $40 \mathrm{mg}$ og $120 \mathrm{mg}$ proantocyanidiner, og hemmingen av adhesjon var i begge studier uavhengig av om bakteriene hadde gener som kodet for Ppili eller hadde antibiotikaresistens $(7,8)$. Rent teoretisk kan bruk av tranebær istedenfor antibiotika redusere risikoen for utvikling av antibiotikaresistente bakterier, men det finnes foreløpig ikke dokumentasjon for dette.

Det er gjort få farmakokinetiske studier på proantocyanidiner. Det skyldes strukturell kompleksitet og mangel på kommersielle standarder. Det er foreløpig ikke isolert proantocyanidiner fra human urin etter inntak av tranebærjuice, og man vet ikke i hvilken grad de metaboliseres. Det finnes ikke dokumentasjon på at tranebær har antiadherent aktivitet etter at bakteriene har festet seg.

\section{Kliniske studier}

I en metaanalyse fra Cochranes kunnskapsoppsummering (januar 2007) ble fire randomiserte, kontrollerte studier inkludert $(\mathrm{n}=665)$. Tranebærproduktene reduserte signifikant antall symptomatiske urinveisinfeksjoner over en 12-månedersperiode (RR 0,66, $95 \%$ KI 0,47-0,92) sammenliknet med placebo. Effekten synes å være størst hos kvinner med ukompliserte, residiverende urinveisinfeksjoner. Effekten for andre grupper (barn, eldre kvinner og menn) var mer usikker, og det ble ikke sett effekt hos personer med kateter. Studiene hadde en varighet på 6-12 måneder (2).

Ut fra denne metaanalysen synes det altså som om den utbredte oppfatning hos leg og lærd om at tranebær virker forebyggende på urinveisinfeksjoner kan bekreftes empi- risk. Det er imidlertid flere svakheter ved studiene. Ingen oppga rasjonale for hvilken dose som ble valgt, den varierte fra $30 \mathrm{ml} /$ dag til $750 \mathrm{ml} / \mathrm{dag}$. Kun i én studie er konsentrasjonen av proantocyanidin oppgitt. I de to studiene med kvinner med ukompliserte, residiverende urinveisinfeksjoner ble det brukt ulike tranebærarter, henholdvis V macrocarpon og V oxycoccus (2). Det er uklart hvilken mengde tranebær som må inntas for å oppnå forventet effekt, og nødvendig intervensjonslengde er heller ikke kjent.

Etter Cochranes kunnskapsoppsummering er det publisert to randomiserte, kontrollerte og dobbeltblindede studier. I begge tok man for seg tranebær og forebygging av symptomatiske urinveisinfeksjoner hos kateterbrukere. I SINBA-studien $(n=305)$ var det ingen effekt på tid til første symptomatiske infeksjon ved bruk av tranebær, metenaminhippurat (Hiprex) eller tranebær og metaminhippurat sammenliknet med placebo (3). I den andre studien $(n=57)$, med kryssforsøksdesign, var det signifikant færre urinveisinfeksjoner i den perioden deltakerne tok tranebær sammenliknet med da de fikk placebo (6 md.) (4). Man kan foreløpig ikke konkludere med effekt hos kateterbrukere.

Et fåtall andre studier er også publisert. Disse er imidlertid for små til å være konklusive. Vi har ikke funnet studier der man har sammenliknet tranebær- og antibiotikabruk. Det trengs kvalitetsstudier med relevant utfall før man kan trekke sikre konklusjoner.

\section{Hovedbudskap}

- Noe dokumentasjon tyder på at tranebær kan forebygge symptomatisk urinveisinfeksjon hos kvinner med risiko for residiverende infeksjoner

- Det mangler dokumentasjon på optimal dosering, administrasjonsform og behandlingslengde

- Farmakodynamisk interaksjon mellom tranebær og warfarin kan ikke utelukkes

- De som er disponert for nyrestein, bør unngå bruk av tranebær i antatt terapeutiske doser

- Tranebær anbefales ikke brukt i antatt terapeutiske doser hos gravide og ammende 


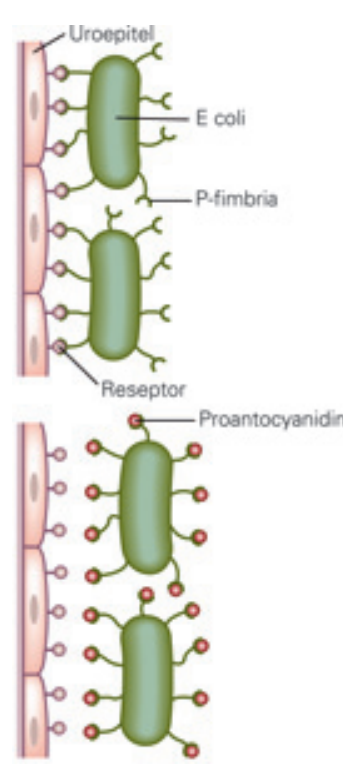

Figur 1 Skjematisk fremstilling av antatt virkningsmekanisme. In vitro-studier har vist at tre A-type proantocyanidintrimere fra tranebær hemmer adheranse av patogene Escherichia coli til uroepitelceller

\section{Bivirkninger}

Sikkerhetsprofilen til tranebær er ikke systematisk studert, men det er få rapporter om bivirkninger. I noen av studiene var det imidlertid et stort frafall (20-50\%). Gastrointestinale plager og vond smak ble oppgitt som hovedårsaker. På grunn av høyt oksalatinnhold kan inntak av mer enn 11 juice daglig over en lengre periode øke risikoen for danning av nyrestein (6). Det anbefales at pasienter med risiko for å få nyrestein unngår bruk av tranebær. Diabetikere bør være oppmerksomme på at tranebærjuice er tilsatt store mengde sukker. Inntak av tranebær i form av kapsler og tabletter bør foretrekkes, da det gir lavere kalori-/sukkerinntak.

\section{Interaksjoner}

I 2004 advarte engelske legemiddelmyndigheter mot å kombinere tranebær og warfarin. Bakgrunnen for dette var 12 kasuistikker der det var mistanke om interaksjon. Flere er publisert i etterkant. Nylig publiserte kontrollerte kliniske studier indikerer imidlertid at det ikke foreligger farmakokinetiske interaksjoner mellom tranebær og warfarin ved daglig inntak av inntil $600 \mathrm{ml}$ tranebærjuice $(9,10)$. Det er motstridende resultater fra kontrollerte kryssundersøkelser der man har undersøkt en potensiell farmakodynamisk interaksjon mellom tranebær og warfarin, men foreløpig kan man ikke utelukke at tranebær kan endre warfarinets farmakodynamikk og potensielt gi signifikant økt effekt av midlet.

Skal man følge «føre var»-prinsippet, bør pasienter som står på warfarin unngå å bruke tranebærprodukter som profylakse mot urinveisinfeksjoner. Velges det allikevel å bruke tranebær, anbefales det nøye monitorering

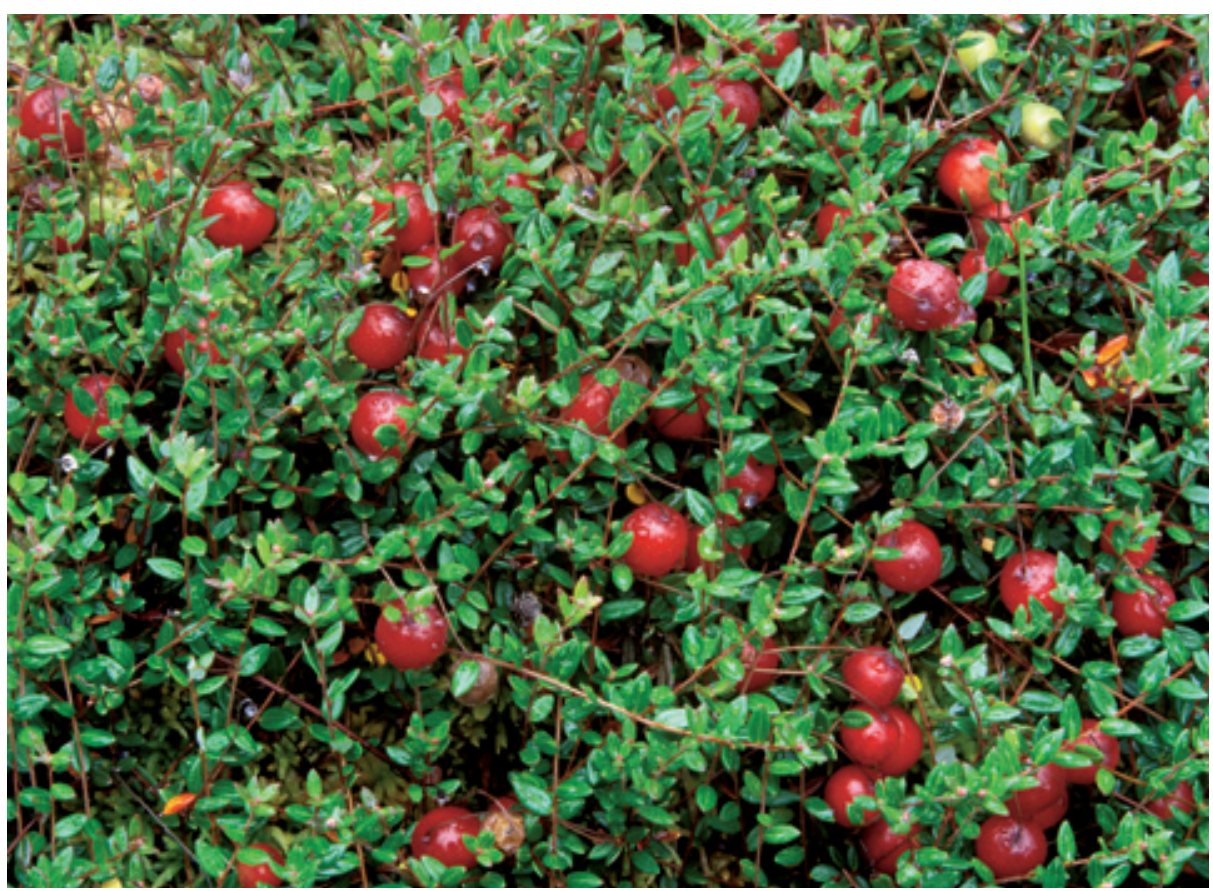

Figur 2 Tranebær tilhører lyngfamilien. Bildet viser en europeisk art (V oxycoccus) fotografert på myr i Ishavet naturreservat i Vestby, Follo. Foto @ Øystein Søbye/NN/Samfoto

av endringer i INR-nivå, og pasienten må gjøres oppmerksom på tegn og symptomer på blødning.

\section{Graviditet og amming}

Flere kliniske studier om bruk av tranebær hos gravide er underveis (www.clinicaltrials.gov). Foreløpig finnes det for lite dokumentasjon vedrørende bruk av antatt terapeutiske doser under graviditet og amming til at slik bruk kan anbefales (5).

På det norske markedet finnes det produkter der tranebær er kombinert med bucco-/ buchuekstrakt (Barosma betulina). Ekstrakter fra $\mathrm{B}$ betulina er kontraindisert under graviditet og amming pga. innhold av pulegon, et kjent hepatotoksin. Det er også mistanke om abortfremkallende egenskaper (5).

Siden det fortsatt er mangelfull dokumentasjonen, vurderer vi at den potensielle nytten ikke står i forhold til mulig risiko.

\section{Konklusjon}

De data som foreligger, tyder på at tranebær kan forebygge urinveisinfeksjon hos kvinner med risiko for residiverende infeksjoner. Imidlertid mangler det anbefalinger om optimal dosering (mengde per dag og konsentrasjon av juice-/tranebærprodukt), om administrasjonsform (juice/kapsler/tabletter) og behandlingslengde. Før vi kan trekke sikre konklusjoner trengs det godt designede kliniske studier der tranebærpreparatene er tilstrekkelig standardisert.

\section{Cecilie Sogn Nergård}

cecilie.nergard@relis.ulleval.no Vigdis Solhaug

RELIS Øst

Ullevål universitetssykehus 0407 Oslo
Oppgitte interessekonflikter: Ingen

e-ramme 1 finnes i artikkelen på www.tidsskriftet.no

\section{Litteratur}

1. Nordeng $H$, Havnen GC. Use of herbal drugs in pregnancy: a survey among 400 Norwegian women. Pharmacoepidemiol Drug Saf 2004; 13 . 371-80.

2. Jepson RG, Craig JC. Cranberries for preventing urinary tract infections. Cochrane Database Syst Rev 2008; nr. 1: CD0001321.

3. Lee BB, Haran MJ, Hunt LM et al. Spinal-injured neuropathic bladder antisepsis (SINBA) trial. Spinal Cord 2007; 45: 542-50.

4. Hess MJ, Hess PE, Sullivan MR et al. Evaluation of cranberry tablets for prevention of urinary tract infections in spinal cord injured patients with neurogenic bladder. Spinal Cord 2008; 46: 622-6.

5. Natural Medicines Comprehensive Database. Cranberry, Buchu. www.naturaldatabase.com (27.5.2008).

6. Foo LY, Yinrong L, Howell AB et al. A-type proanthocyanidin trimers from Cranberry that inhibit adherence of uropathogenic P-fimbriated Eschericia coli. J Nat Prod 2000; 63: 1225-8.

7. De Martino P. Agniel R, David K et al. Reduction of Escherichia coli adherence to uroepithelial bladde cells after consumption of cranberry juice: a double-blind randomized placebo-controlled cross-over trial. World J Urol 2006: 24: 21 -7.

8. Lavigne JP, Bourg G, Combescure C et al. In-vitro and in-vivo evidence of dose-dependent decrease of uropathogenic Escherichia coli virulence after constumption of commercial Vaccinium macrocarpon (cranberry) capsules. Clin Microbiol Infect 2008; 14: $350-5$

9. Lilja JJ, Backman JT, Neuvonen PJ. Effects of daily ingestion of cranberry juice on the pharmacogenetics of warfarin, tizanidine, and midazolamprobes of CYP2C9, CYP1A2, and CYP3A4. Clin Pharmacol Ther 2007; 81: 833-9

10. Mohammed Abdul MI, Jiang X, Williams KM et al. Pharmacodynamic interaction of warfarin with cranberry but not with garlic in healthy subjects. Br J Pharmacol 2008: 154: 1691-700. 